\title{
A Familial Variant of Chromosome 9
}

\author{
CATHERINE G. PALMER and JANE SCHRODER \\ From the Department of Medical Genetics, Indiana University Medical Center, Indianapolis, Indiana, USA
}

In 1966 Court Brown et al described a group of heritable human chromosomal variants which appeared to lack detectable phenotypic effects. These variant or marker chromsomes appear longer and have altered morphology and arm ratio. Court Brown suggested that the morphological differences generally resulted from changes in length at the secondary constrictions. In his series of 756 subjects, approximately $2 \cdot 7 \%$ showed this type of variation mainly involving members of groups $D, E$, and G. Another $2.6 \%$ of the males had differences in the size of the $\mathrm{Y}$ chromosome.

Though Court Brown did not find variants of autosome 1 or of the $\mathrm{C}$ group chromosome which carries a characteristic secondary constriction $\left(C^{\prime}\right.$ or 9), he predicted that such variability should occur. Several examples of heteromorphic pairs of chromosome 1 had been described (Cooper and Hernits, 1963; Yunis and Gorlin, 1963) at the time of his report and since then additional examples of marker 1 chromosomes have appeared (Donahue et al, 1968; microcephaly (OFC $35 \mathrm{~cm}$ ), low set ears, and flexion deformities (overlapping of 4 th and 5th fingers) of both hands. She was otherwise clinically normal and had no dermatoglyphic abnormalities. The patient, weighing $2239 \mathrm{~g}$ at birth, was the product of a dizygotic twin pregnancy and had subsequently failed to thrive. Her twin was a normal male.

The family history records a maternal sister with a congenital heart defect and two mentally retarded paternal half sibs. A number of paternal relatives have talipes equinovarus (see Fig. 1).

\section{Chromosomal Findings}

Cells of peripheral blood and skin cultures of the patient had 46,XX chromosomes with a $C$ group member carrying an unusually long paracentric secondary constriction in the long arm (Figs. 2 and 3). In this region the chromatids were in close proximity. The length of this chromosome often caused it to be identified at the microscope as a member of the $B$ group, and in a number of cells the paracentric region appeared to be duplicated. The length of the secondary constriction

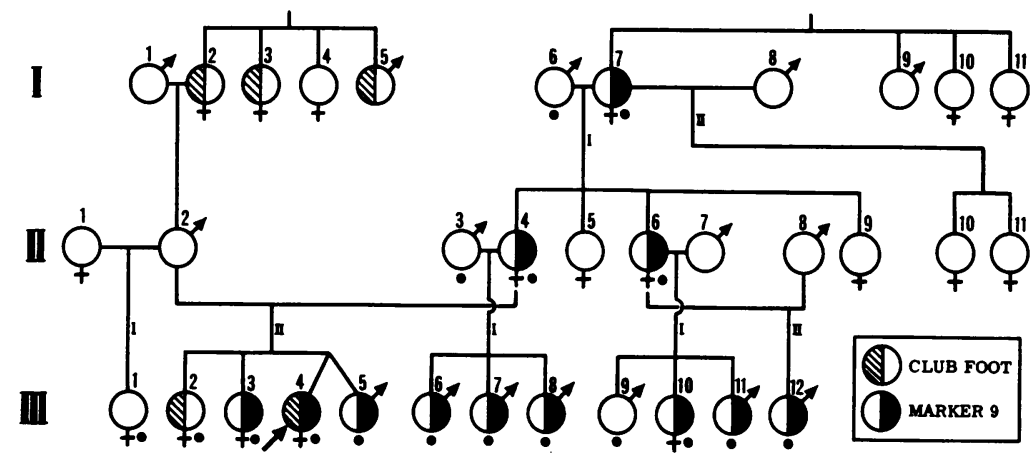

FIG. 1. Pedigree of family showing 3 generations carrying the marker chromosome. Dots indicate those individuals studied cytologically.

Ying and Ives, 1968). The purpose of this report is to describe a family in which such a heteromorphic chromosome 9 was segregating.

\section{Clinical Findings}

The patient was a $2 \frac{1}{2}$-month-old female with multiple congenital anomalies including talipes equinovarus,

Received 16 June 1970. varied from cell to cell with the degree of contraction of the other chromosomes of the nucleus. In some cells it could not be differentiated from the other $\mathrm{C}$ chromosomes. When other family members were studied, the marker chromosome was found to be present in cells of the mother, her sister, children of both women, and in the maternal grandmother (Fig. 1). The marker appeared in varying frequency in the different members of the family and in the different tissues of the proband 


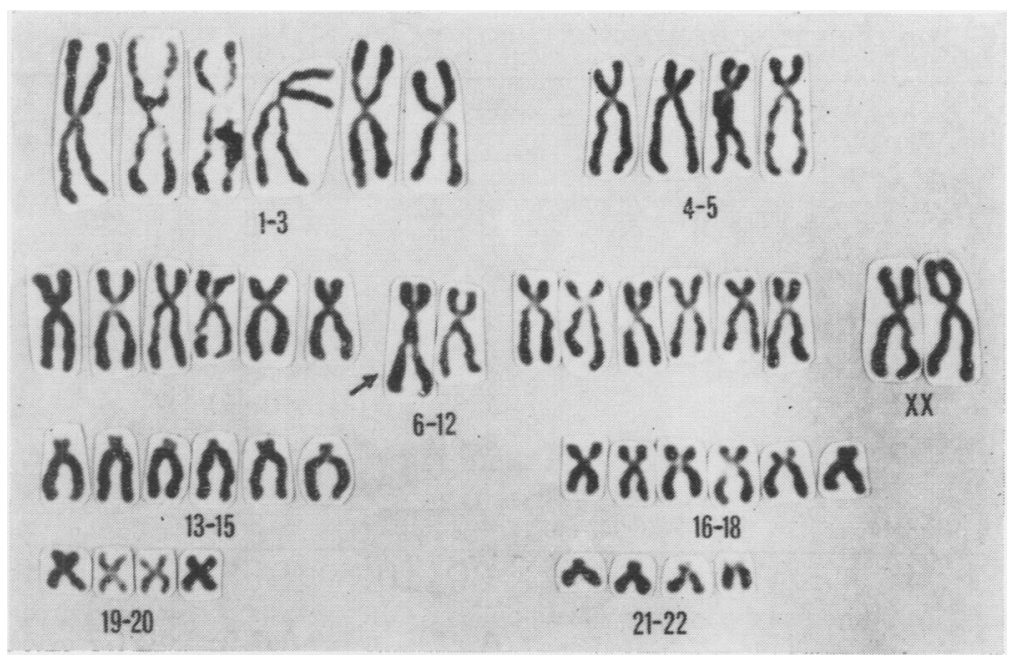

Fig. 2. Karyotype showing the marker 9 chromosome of patient (III.4).

(Table I). Additional family members refused to participate in the study.

Karyotype analysis suggested that the abnormal chromosome was probably a long chromosome 9 . The 9 with the normally occurring secondary constriction could be observed as well as the marker 9 in a number of cells. If the marker,chromosome were homologous to chromo-

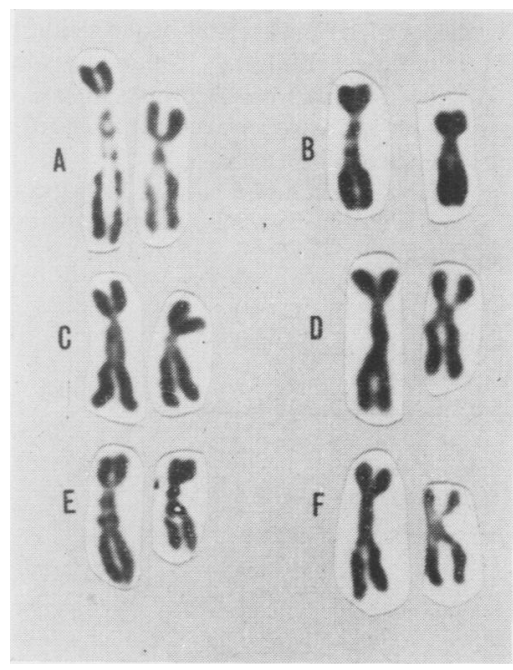

Fig. 3. Marker chromosome and homologue from patient (A) and other family members (B-F) showing extended secondary constriction.

some 9 which ordinarily carries a constriction, more than one such constriction bearing 9 should not occur in any cell.

The 9 constriction and that of the marker in several family members were compared in cultured leucocytes which were treated with BUdR (5-bromo deoxyuridine $75 \mu \mathrm{g} / \mathrm{ml}$ ) for the last 6 hours of growth in calcium-free medium (BME spinner medium). This drug has been found to increase the frequency of normally occurring secondary constrictions and induce additional constrictions which may be used as morphological markers in the human complement (Kaback, Saksela, and Mellman, 1964; Palmer and Funderburk, 1965; Palmer, 1968; Brown and Palmer, unpublished). The cells were scored for the presence of the marker chromosome and the number of other $\mathbf{C}$ group chromosomes with a proximal secondary constriction. If the marker represents an extended region of chromosome 9 , one would predict that not more than one additional 9 would be found and that the constriction could be differentiated from the marker. Table II shows the results of BUdR treatment of cells of 4 family members, 3 of whom carry the abnormal chromosome and one additional control. In no case was more than one chromosome 9 recorded in addition to the marker chromosome.

Mitomycin C preferentially induces breaks and rearrangements at the secondary constrictions of chromosomes 1, 9, and 16 (Cohen and Shaw, 1966) and produces attenuated constrictions in these chromosomes, most significantly in chromosome 9. Mitomycin C (Bristol, $0.1 \mu \mathrm{g} / \mathrm{ml}$ for 24 hours) was therefore used to treat leucocyte cultures (in Chromosome Medium 1a; Grand Island Biological Co.) of the patient's mother. The cells were scored for the occurrence of exchanges and the number of constricted 9 chromosomes in addition to the marker in the cell.

Analysis of karyotypes of cells with rearrangements showed that seven of the 16 quadriradials involved the marker and chromosome 9 thus providing evidence for homology (Table III; Fig. 4). When constrictions were scored after mitomycin treatment, only one 
TABLE I

DISTRIBUTION OF MARKER CHROMOSOME IN FAMILY MEMBERS

\begin{tabular}{|c|c|c|c|c|c|c|c|}
\hline \multirow{2}{*}{\multicolumn{2}{|c|}{ Subject }} & \multirow{2}{*}{ Tissue } & \multicolumn{4}{|c|}{ Number of Cells } & \multirow{2}{*}{$\begin{array}{c}\% \\
\text { of Cells with } \\
\text { Marker }\end{array}$} \\
\hline & & & $\begin{array}{c}\text { Marker } \\
\text { Only }\end{array}$ & $\begin{array}{c}\text { Marker + } \\
\text { Constricted } 9\end{array}$ & $\begin{array}{c}\text { No } \\
\text { Marker }\end{array}$ & Total & \\
\hline $\begin{array}{l}\text { III.4 } \\
\text { III.1 } \\
\text { IIII.2 } \\
\text { III.5 } \\
\text { III.6 } \\
\text { III.7 } \\
\text { III. } 8 \\
\text { I.7 } \\
\text { I.6 } \\
\text { III.9 } \\
\text { III.12 } \\
\text { III.10 } \\
\text { II.6 } \\
\text { III.11 }\end{array}$ & $\begin{array}{l}\mathbf{F} \\
\mathbf{F} \\
\mathbf{F} \\
\mathbf{M} \\
\mathbf{M} \\
\mathbf{M} \\
\mathbf{M} \\
\mathbf{F} \\
\mathbf{M} \\
\mathbf{M} \\
\mathbf{M} \\
\mathbf{F} \\
\mathbf{F} \\
\mathbf{M}\end{array}$ & $\begin{array}{c}\text { Leucocytes } \\
\text { Skin } \\
\text { Leucocytes } \\
\text { ", } \\
\text { ", } \\
\text { ", } \\
\text { " } \\
\text { " } \\
\text { " } \\
\text { " }\end{array}$ & $\begin{array}{r}39 \\
23 \\
0 \\
0 \\
7 \\
11 \\
42 \\
6 \\
9 \\
0 \\
0 \\
20 \\
15 \\
24 \\
17\end{array}$ & $\begin{array}{l}2 \\
3 \\
0 \\
0 \\
0 \\
0 \\
1 \\
0 \\
0 \\
0 \\
0 \\
0 \\
2 \\
0 \\
2\end{array}$ & $\begin{array}{l}5 \\
65 \\
35 \\
24 \\
21 \\
16 \\
16 \\
42 \\
21 \\
19 \\
36 \\
15 \\
28 \\
25 \\
11\end{array}$ & $\begin{array}{l}56 \\
91 \\
35 \\
24 \\
28 \\
27 \\
59 \\
48 \\
30 \\
19 \\
36 \\
35 \\
45 \\
49 \\
30\end{array}$ & $\begin{array}{r}69 \\
25 \\
0 \\
0 \\
25 \\
41 \\
71 \\
13 \\
30 \\
0 \\
0 \\
57 \\
30 \\
50 \\
56\end{array}$ \\
\hline
\end{tabular}

constriction-bearing 9 in addition to the marker was observed (Table III), thus supporting the BUdR findings.

Autoradiography of cells with the marker chromosome shows the paracentric constriction to be late replicating. In some cells most of the synthesis was completed with the exception of late $X$ and the paracentric constriction ofthe marker (Fig. 5). In others the marker incorporated ${ }^{3} \mathrm{H}$ thymidine at the same time as the late regions of the $\mathrm{D}$ chromosomes.

Measurements of homologues of the proband and of carrier individuals indicate that the arm ratios are similar to those given for chromosome 9 in the Denver classification (Table IV). The measurements also indicate the degree of difference in the normal constriction-bearing 9 and the marker. An analysis of variance of arm ratios in the 8 carriers showed no significant differences between subjects but significant differences between the marker and its homologue ( $F=11.361$; df 36,1$)$. The arm ratio of the proband's chromosome is smaller than that of carrier individuals but the apparent difference is not significant $(F=0.574 ; \mathrm{df} 8,64)$.

\section{Linkage Data}

The family was studied for evidence of linkage between the marker chromosome and 9 polymorphic systems. Blood typing was performed on all available family members and a summery of the blood group, haptoglobin, phosphoglucomutase, and acid phosphatase markers is given in the Appendix (p. 208).

Linkage analysis was performed by the lod score method of Morton (1955). Maximum likelihood estimates were obtained by iteration. For test factors showing dominance, a family was scored only if the genotypes of both parents were known or could be inferred from their children's phenotypes. The phase of linkage for $\mathrm{ABO}, \mathrm{Rh}$, and MNS was established using the genotypes of $\mathrm{I.7}$ and her children. Since the main factor (marker 9) is co-dominant, ascertainment was complete and no correction terms were necessary (Morton, 1955). The results are shown in Table $\mathrm{V}$.

Linkage analysis excluded close linkage $(\theta<0 \cdot 10)$ with one of the 9 loci but was consistent with loose linkage for 3 of the loci.

TABLE II

DISTRIBUTION OF MARKER AND CHROMOSOME 9* WITH CONSTRICTION IN BUdR CULTURES

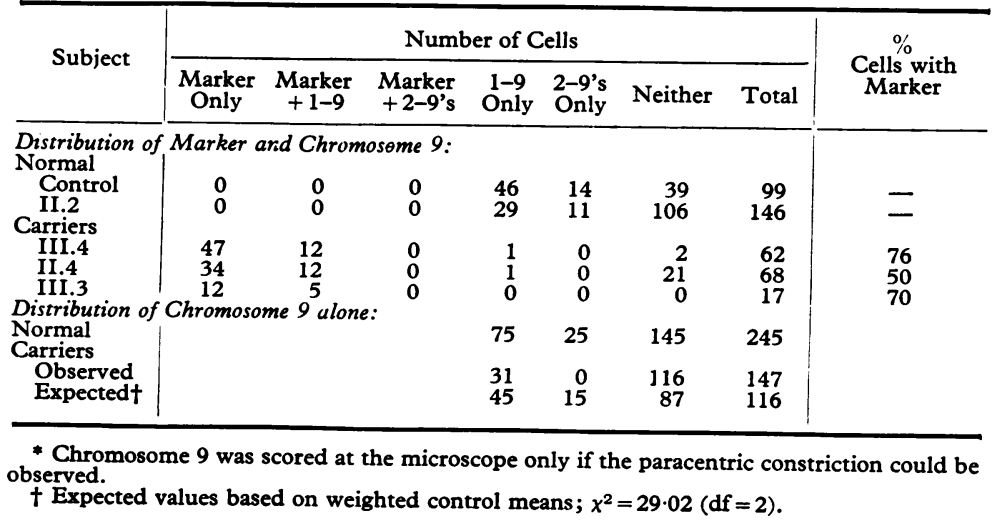


TABLE III

\section{CHROMOSOME FINDINGS IN MITOMYCIN CULTURES}

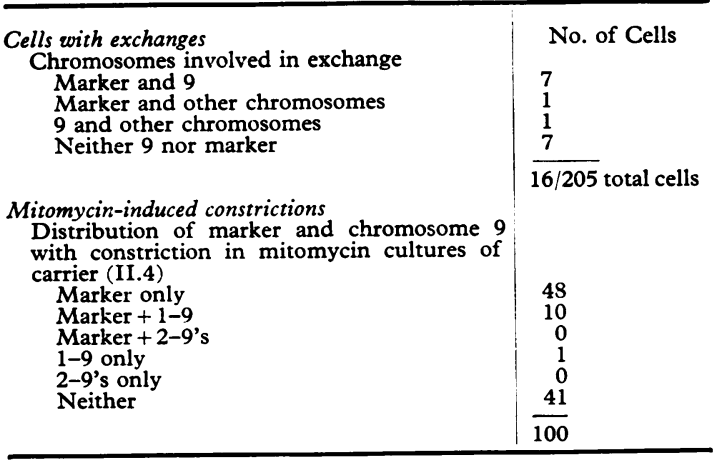

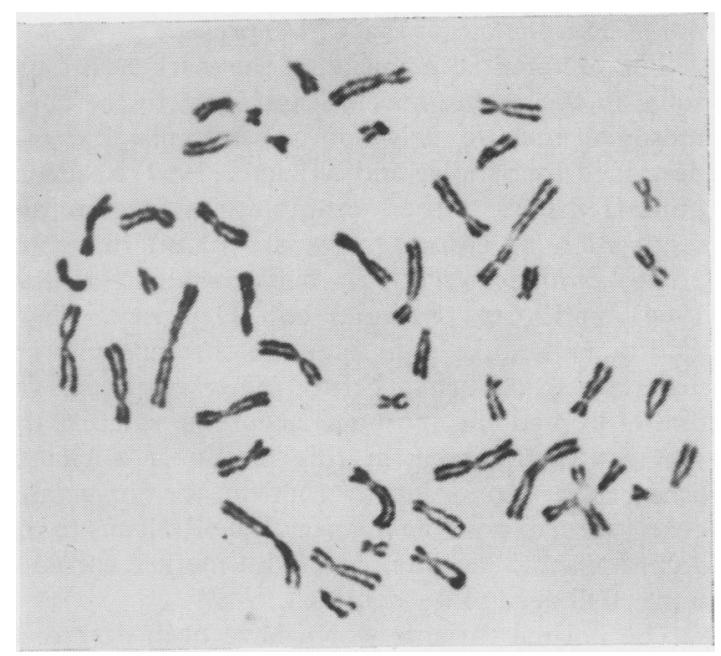

Fig. 4. Mitomycin C treated leucocyte culture showing quadriradial involving marker 9 and homologue.

The greatest positive $Z$ score was obtained with the $R h$ locus. A maximum $Z$ score of 1.203 was observed at $\theta=0.159$ corresponding to a probability ratio of 15.96 to 1 favouring linkage.

Since only mothers were segregating, the typing results could not be further analysed to search for linkage heterogeneity between sexes (Nance et al, 1970).

\section{Segregation of the Marker}

Carrier mothers transmitted the marker chromosome to 9 of 11 children of two sisters (II.4 and II.6 in Fig. 1). The marker chromosome was transmitted to both male and female progeny. Assuming a segregation ratio of 0.5 , the deviation from normal segregation fell short of significance at the $5 \%$ level $(\mathrm{p}=0.066)$ using a twotailed test. However, it is possible that there is preferential segregation of the marker chromosome into the functional oocyte. If we analyse the data for pre- ferential inclusion using a one-tailed test, the probability of the observed results is significant $(p=0.033)$.

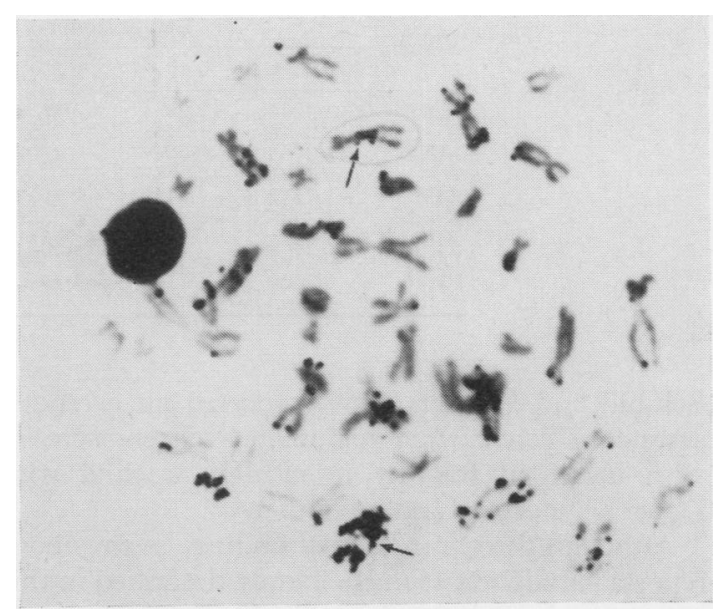

FIG. 5. Autoradiograph of cell grown in tritiated thymidine for terminal $4 \frac{1}{2}$ hours of culture. Replicating regions include $X$ chromosome and long construction in 9 (arrows).

TABLE IV

MEASUREMENTS OF MARKER NO. 9 AND ITS NORMAL HOMOLOGUE

\begin{tabular}{|c|c|c|c|c|}
\hline Individual & Chromosome & $\begin{array}{c}\text { Number } \\
\text { of } \\
\text { Cells }\end{array}$ & Arm Ratio & SD \\
\hline & $\begin{array}{l}\text { Normal } \\
\text { Marker }\end{array}$ & $\begin{array}{l}14 \\
14\end{array}$ & $\begin{array}{l}2 \cdot 30 \\
2 \cdot 46\end{array}$ & $\begin{array}{l}0.37 \\
0.41\end{array}$ \\
\hline $\begin{array}{l}\text { Family members with } \\
\text { marker } \\
\text { Chromosome 9 } \\
\text { (Denver Report, 1960) }\end{array}$ & $\begin{array}{l}\text { Normal } \\
\text { Marker }\end{array}$ & $\begin{array}{l}29 \\
29\end{array}$ & $\begin{array}{l}2 \cdot 32 \\
2 \cdot 90 \\
\text { Range } \\
1 \cdot 5-2 \cdot 4\end{array}$ & $\begin{array}{l}0.34 \\
0.44\end{array}$ \\
\hline
\end{tabular}

Discussion

A family has been observed in which a marker chromosome was found in 12 members of 3 generations. The marker is a member of the $C$ group and was identified as being one of the number 9 pair by morphological criteria and by response to BUdR and mitomycin $\mathrm{C}$.

A similar marker chromosome has been reported by Håkansson (1966) in a girl with WerdnigHoffman's muscular dystrophy, and in her mother. Moores, Anders, and Emanuel (1966) in a cytogenetic survey of 250 patients with congenital heart disease found an elongated paracentric constriction in a patient with coarctation of the aorta, and in his mother and one of his daughters. Emerit and Vernant (1968) described a similar chromosome in two brothers with interventricular septal defect, in the mother and also in another unaffected brother. 
TABLE V

RESULTS OF LINKAGE ANALYSIS OF MARKER AND SPECIFIC LOCI

\begin{tabular}{|c|c|c|c|c|c|c|c|}
\hline \multirow{2}{*}{ System } & \multicolumn{5}{|c|}{ Lod Score for Values of $\theta$} & \multirow{2}{*}{ Odds } & \multirow{2}{*}{$\begin{array}{l}\text { Max. } \\
\text { Likelihood } \\
\text { Estimate of } \theta\end{array}$} \\
\hline & 0.05 & $0 \cdot 10$ & 0.20 & 0.30 & 0.40 & & \\
\hline $\begin{array}{l}\text { Hp } \\
\text { Kell } \\
\text { MNS } \\
\text { P } \\
\text { APh } \\
\text { Kidd } \\
\text { ABO } \\
\text { Duffy } \\
\text { Rh }\end{array}$ & $\begin{array}{l}-3.4224 \\
-2.8648 \\
-1.3483 \\
-0.1776 \\
-1.7212 \\
-1.4425 \\
-0.6271 \\
+0.2167 \\
+0.7669\end{array}$ & $\begin{array}{l}-2.2854 \\
-1.7748 \\
-0.6057 \\
-0.1362 \\
-1.1427 \\
-0.8874 \\
-0.1620 \\
+0.1828 \\
+1.1145\end{array}$ & $\begin{array}{l}-1.1834 \\
-0.7752 \\
-0.0397 \\
-0.0732 \\
-0.5917 \\
-0.3876 \\
+0.1541 \\
+0.1158 \\
+1.1746\end{array}$ & $\begin{array}{l}-0.5950 \\
-0.3028 \\
+0.1296 \\
-0.0316 \\
-0.2976 \\
-0.0113 \\
+0.2053 \\
+0.0567 \\
+0.9358\end{array}$ & $\begin{array}{l}-0.2292 \\
-0.0708 \\
+0.1223 \\
-0.0078 \\
-0.1146 \\
-0.0000 \\
+0.1400 \\
+0.0151 \\
+0.5360\end{array}$ & $\begin{array}{l}\bar{z} \\
\overline{1.38} \\
\overline{1} \\
\overline{1 \cdot 61} \\
\overline{15 \cdot 96}\end{array}$ & $\begin{array}{l}\overline{-} \\
\overline{0.343} \\
\overline{-} \\
\overline{0} \cdot 284 \\
\overline{0} \cdot 159\end{array}$ \\
\hline
\end{tabular}

Schmid and Vischer (1969) reported an extended secondary constriction region in a chromosome 9 with increased fragility in vitro in a child with Down's syndrome and her father.

Although the chromosomal findings in the above reports parallel those in the family described in this paper the phenotypic effects do not appear to constitute a distinct syndrome. Our patient had multiple congenital anomalies some of which are probably inherited, ie, club feet. However, none of the clinical findings was observed in the other family members carrying the marker.

The chromosome marker which we have followed could result from a translocation of a $\mathrm{C}$ group chromosome and another unknown chromosome. The clinical defects seen in the patient might then result from duplication or deficiency of genetic material after crossing over in the translocation segment. If a translocation were present, additional abnormal children or miscarriages might be expected, but have not been observed. Alternately, the marker might be a normal variant, resulting from the presence of a gene which alters the degree of coiling at the constriction (Court Brown et al, 1966). A third possibility is that duplication of a heterochromatic segment has occurred or that insertion of a euchromatic segment in the constriction region has rendered the segment heterochromatic. The late replication of the paracentric constriction and the lack of clinical defects in many family members might support this hypotheses. The seeming doubleness of the region might also argue for duplication or insertion in preference to a genetically controlled change in coiling.

Reports of similar extension of constrictions and asymmetry of the arms in chromosome 1 have been subject to several interpretations; one group favouring the 'uncoiler' concept (Donahue et al, 1968) and the other favouring an insertion of euchromatic material (Ying and Ives, 1968).

A survey of our patient files for similar families yielded one additional family* with a long constriction in 9 (for a frequency of $2 / 730$ patients). This second variant, however, was neither as long nor as conspicuous as that of the present family.

The preferential inclusion of the marker chromosome in the oocyte may be compared to the chromosomal meiotic drive of a heteromorphic pair described by Sandler and Novitski (1957) in drosophila females. Other examples of preferential segregation of chromosomes are found in drosophila (Zimmering, 1955), haplopappus (Jackson, 1964), and corn (Rhoades and Dempsey, 1966). Additional families with marker 9 chromosomes are necessary to confirm whether preferential segregation of human chromosomes occurs or whether the segregation observed in this family is a chance occurrence. In order to confirm the suggestive observation of possible linkage of the $\mathrm{Rh}$ locus to the 9 chromosome more families with marker chromosomes will need to be identified.

The normal variants which have been described in other chromosomes are mainly confined to the secondary constriction region, satellites, and short arms of the acrocentric chromosomes, the secondary constrictions of the $\mathrm{E}$ group, the heterochromatic segment of the long arm of the $\mathrm{Y}$ chromosome, and the secondary constriction region of chromosome 1 (Court Brown et al, 1966; Sands, 1969). In the variant chromosome described in this paper the constriction region is similarly involved suggesting a dispensability to these regions and a resulting variability of size in constriction-bearing chromosomes.

Court Brown et al (1966) did not include such $C^{\prime}$ or 9 variants in their survey of normal adults. Standard laboratory procedures do not always reveal secondary constrictions since they are influenced by concentration and duration of colcemide

* The consanguinity in the additional family reduces its usefulness for linkage or segregation studies. 
treatment (Palmer and Funderburk, 1965), hypotonic method (Bruere and McLaren, 1967), and fixative and slide-making methodology (Saksela and Moorhead, 1962). Continued efforts to improve standard techniques should reveal additional chromosome detail and such markers as the one described which must then be differentiated from chromosomal rearrangements. The utilization of special methods such as BUdR or mitomycin treatment might enable better identification of the chromosomes and even recognition of small rearrangements which cannot now be ascertained.

\section{Summary}

This paper presents a family with a variant chromosome 9 in which a long secondary constriction was found in 12 members of 3 generations. The marker was identified as being one of the $9 \mathrm{~s}$ by morphological criteria and by response to BUdR and Mitomycin C. Linkage analysis indicates a possible linkage of the $\mathrm{Rh}$ locus to the 9 chromosomes. The possibility of preferential inclusion of the marker chromosome in the oocytes of carrier mothers is suggested.

This investigation was supported in part by a Career Development Award (5-K $\left.\mathrm{K}_{3}-\mathrm{GM}-16\right)$ to Dr C. G. Palmer, a NDEA Title IV Fellowship to J. Schroder, and a grant from the Marion County Cancer Society and the James Whitcomb Riley Memorial Association.

The authors wish to thank Judy Morris and Jeannine Kuykendall for cytogenetic technical assistance and Jim Eisenhut for performing the genotyping.

\section{REFERENCES}

Bruere, A. N. and McLaren, R. D. (1967). The idiogram of the sheep with particular reference to secondary constrictions. Canadian Fournal of Genetics and Cytology, 9, 543-553.

Cohen, M. M. and Shaw, M. W. (1964). Effects of Mitomycin C on human chromosomes. Fournal of Cell Biology, 23, 386-394.
Cooper, H. L. and Hernits, R. (1963). A familial chromosome variant in a subject with anomalous sex differentiation. American fournal of Human Genetics, 15, 465-475.

Court Brown, W. M., Buckton, K. E., Jacobs, P. A., Tough, I. M., Kuenssberg, E. V., and Knox, J. D. E. (1966). Chromosome Studies on Adults. Cambridge University Press, London.

Denver Conference (1960). A proposed standard system of nomenclature of human mitotic chromosomes. Lancet, 1, 1063-1065.

Donahue, R. P., Bias, X. B., Renwick, J. H., and McKusick, V. A. (1968). Probable assignment of the Duffy blood group locus to chromosome 1 in man. Proceedings of the National Academy of Sciences of the United States of America, 61, 949-955.

Emerit, I. and Vernant, P. (1968). Anomalie d'un chromosome du groupe $\mathbf{C}$ chez plusieurs membres d'une même famille. Humangenetik, 6, 326-334.

Hăkansson, L. (1966). A case of Werdnig-Hoffman muscular dystrophy with an unusual chromosome complement. Hereditas Genetiskt Arkiv, 55, 358-361.

Jackson, R. C. (1964). Preferential segregation of chromosomes from a trivalent in Haplopappus gracilis. Science, 145, 511-513.

Kaback, M. M., Saksela, E., and Mellman, W. J. (1964). The effect of 5-bromodeoxyuridine on human chromosomes. Experimental Cell Research, 34, 182-212.

Moores, E. C., Anders, J. M., and Emanuel, R. (1966). Inheritance of marker chromosomes from a cytogenetic survey of congenital heart disease. Annals of Human Genetics 30, 77-84.

Morton, N. E. (1955). Sequential tests for the detection of linkage. American fournal of Human Genetics, 7, 277-318.

Nance, W. E., Canneally, M., Kang, K. W., Reed, T., Schroder, J., and Rose, S. (1970). Genetic linkage analysis of human hemoglobin variants. American fournal of Human Genetics, 22, 453459.

Palmer, C. G. (1968). BUdR constrictions in human chromosomes (abst.). Proceedings XII International Congress of Genetics, p. 214.

Palmer, C. G. and Funderburk, S. (1965). Secondary constrictions in human chromosomes. Cytogenetics, 4, 261-276.

Rhoades, M. M. and Dempsey, E. (1966). The effect of abnormal chromosome 10 on preferential segregation and crossing over in maize. Genetics, 53, 989-1020.

Saksela, E. and Moorhead, P. S. (1962). Enhancement of secondary constrictions and the heterochromatic $X$ in human cells. Cytogenetics, 1, 225-244.

Sandler, L. and Novitski, E. (1957). Meiotic drive as an evolutionary force. American Naturalist, 91, 105-110.

Sands, V. E. (1969). Short arm enlargement in acrocentric chromosomes. American fournal of Human Genetics, 21, 293-304.

Schmid, W. and Vischer, D. (1969). Spontaneous fragility of an abnormally wide secondary constriction region in a human chromosome no. 9. Humangenetik, 7, 22-27.

Ying, K. L. and Ives, J. (1968). Asymmetry of chromosome no. 1 pair in three generations of a phenotypically normal family. Canadian fournal of Genetics and Cytology, 10, 575-589.

Yunis, J. J. and Gorlin, R. J. (1963). Chromosomal study in patients with cysts of the jaw, multiple nevoid basal cell carcinomata and bifid rib syndrome. Chromosoma, 14, 146-153.

Zimmering, S. (1955). A genetic study of segregation in a translocation heterozygote in Drosophila. Genetics, 40, 809-825. 


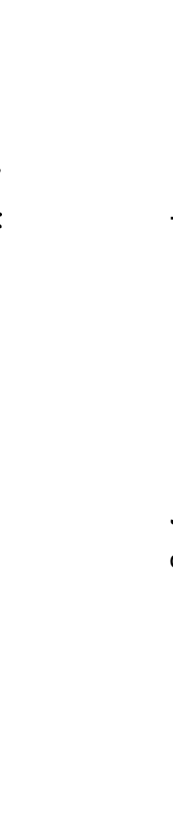

* Haptoglobin

+ Phosphoglumutase

$\ddagger$ Acid phosphatase

APPENDIX

Genotyping Data

\begin{tabular}{|c|c|c|c|c|c|c|c|c|c|c|c|}
\hline Pedigree & Marker & $\mathrm{ABO}$ & Rhesus & MNS & Duffy & Kidd & Kell & $\mathbf{P}$ & $\mathrm{Hp}^{*}$ & PGM† & $\mathrm{AP} \ddagger$ \\
\hline II. 2 & o & $A_{1}$ & $\mathbf{R}_{1} \mathbf{R}_{1}$ & $\mathbf{M} \overline{\mathbf{s}}$ & + & - & - & NT & $2-1$ & $1-1$ & $\mathrm{AA}$ \\
\hline II. 4 & + & $A_{1}$ & $R_{1} r$ & MNs̄ & + & + & + & NT & $2-2$ & $1-1$ & BB \\
\hline III. 2 & 0 & $A_{1}$ & $R_{1} R_{1}$ & $\mathbf{M} \overline{\mathbf{s}}$ & + & + & - & NT & $2-1$ & $1-1$ & BA \\
\hline III. 3 & + & $A_{1}$ & $\mathbf{R}_{1} \mathbf{R}_{1}$ & $\mathbf{M} \overline{\mathbf{s}}$ & - & + & + & NT & $2-1$ & $1-1$ & $\mathrm{BA}$ \\
\hline III.4 & + & $\mathbf{A}_{2}$ & $R_{1} \mathrm{r}$ & MNs & - & - & - & NT & $2-1$ & $1-1$ & $\mathbf{B A}$ \\
\hline III. 5 & + & $\mathrm{A}_{2}$ & $R_{1} r$ & $\mathbf{M s}$ & + & + & - & NT & $2-1$ & $1-1$ & BA \\
\hline III. 6 & + & 0 & $R_{1} R_{1}$ & MNs̄s & + & + & - & NT & $2-2$ & $2-1$ & BA \\
\hline III.7 & + & $A_{1}$ & $\mathrm{rr}$ & Ms & + & + & + & NT & $2-2$ & $1-1$ & $\mathrm{BB}$ \\
\hline III. 8 & + & $A_{1}$ & $\mathrm{rr}$ & MS̄̄ & + & + & + & NT & $1-1$ & $1-1$ & BA \\
\hline II. 6 & + & B & $\mathrm{R}_{2} \mathrm{r}$ & $M N_{\bar{s}}$ & $\div$ & + & + & + & $2-1$ & $1-1$ & BA \\
\hline III. 9 & o & $\mathrm{A}_{2} \mathrm{~B}$ & $\mathrm{R}_{1} \mathbf{R}_{2}$ & $\mathrm{Ns}$ & + & + & + & + & $2-2$ & $1-1$ & $\mathrm{BB}$ \\
\hline III. 10 & + & $\mathrm{A}_{2} \mathrm{~B}$ & $R_{1} \mathrm{r}$ & MNs & - & + & + & + & $1-1$ & $1-1$ & $\mathrm{AA}$ \\
\hline III.11 & + & $\mathrm{A}_{2} \mathrm{~B}$ & $R_{1} r$ & $\mathrm{Ns}$ & + & + & + & + & $2-1$ & $1-1$ & BB \\
\hline III.12 & + & B & $\mathbf{R}_{1} \mathbf{r}$ & MNS $\bar{s}$ & - & + & - & - & $1-1$ & $1-1$ & BB \\
\hline III.1 & O & $\mathrm{A}_{1}$ & $\mathbf{R}_{1} \mathbf{r}$ & $\mathrm{MNs}$ & + & + & - & NT & $2-2$ & $1-1$ & BA \\
\hline I. 6 & 0 & $A_{1} B$ & $\mathbf{R}_{1} \mathbf{R}_{2}$ & Ns̄ & + & + & + & NT & $1-1$ & $1-1$ & BA \\
\hline I. 7 & + & $\mathrm{A}_{1}$ & $R_{1} \mathbf{r}$ & $\mathrm{MNs}$ & + & + & - & NT & $2-2$ & $1-1$ & BB \\
\hline
\end{tabular}

